\title{
The sustainable tourism organization of rural spaces. The island of Sardinia in the era of "staycation"
}

\author{
Brunella Brundu $^{\text {a }}$, Silvia Battino ${ }^{\text {a* }}$, Ivo Manca $^{a}$ \\ ${ }^{a}$ Department of Economics and Business, University of Sassari, Brunella Brundu-brundubr@ uniss.it, Silvia Battino - \\ sbattino@uniss.it,Ivo Manca-ivomanca@uniss.it. \\ * Corresponding author
}

\begin{abstract}
What future for tourism in the COVID-19 era? This is a question that has become part of the daily life of many tourist destinations. The pandemic has affected all economic sectors and tourism is one of the sectors most suffered. According to data from the World Tourism Organization (2021) due to the health emergency $100 \%$ of countries have introduced restrictions in the travel sector and for this reason international tourist arrivals dropping by $74 \%$ in 2020 . Future projections indicate 2023 as the year when a the "regular" flow of tourists can be recorded globally. However, in the meantime, there is a need to improve this sector by implementing strategies to promote and enhance the places to motivate sustainable tourism. The insecurity of travel and of some destinations, due to the many emergency restrictions, pushes tourists to live an outdoor vacation in contact with nature and host community. Thus, the search for authentic places moves minds more consciously towards sustainable tourism practices showing a greater interest in some forms of tourism such as rural and cultural.

The aim of this work is to understand how to deal with the "new" needs of the demand, bringing out the rural realities through the creation of an organized sustainable offer that revolves around existing accommodation facilities such as farmhouses. In particular, the case of Sardinia will be analyzed, an island that has long been known for its seaside tourism, but whose rural and internal areas are still not much used touristically. The study intends, after a short review of the literature on the sustainability of rural tourism, highlight the possibility to create rural tourist itineraries capable of enhancing the territory's peculiarities by combining the different landscape assets. The exemplification of the creation of these routes will be realized in GIS field through the creation of a model of accessibility to the Sardinian rural space. This model will be based on the use of isochronous curves obtained from the analysis of travel times both to move towards and from the agritourism that offer accommodation and within their landscape offer.
\end{abstract}

Keywords: COVID-19, sustainable tourism, agrotourism, GIS, Sardinia 


\section{Introduction}

The health emergency caused by the COVID-19 virus that began in 2020 has significantly changed the social and economic life of every single country. One of the economic sectors marked by the greatest suffering is tourism which, in the same year, reported a significant reduction in international departures equal to $-74 \%$ compared to 2019 (Gossling, Scott, Hall, 2020; https: //www.unwto .org / tourism-covid-19). Health restrictions and insecurity in movements by the world population continue to represent an element of instability for the travel sector also in 2021 and according to the forecasts and estimates made by the World Tourism Organization only between July and September there could be a partial but positive change of tourism demand. Future trips for holidays are mainly motivated by the need of the "traveling" communities to find new balances that can help to forget the important difficulties created by the pandemic. Several studies have highlighted the need for holidays in the open air and in greater contact with natural spaces (Everingham, Chassagne, 2020; Fletcher et al., 2020; Ioannides, Gyimòthy, 2020; Sharma, Thomas, Paul, 2021). These "wishes" of tourists thus underline how the slow philosophy inherent in the definition of rural tourism is the response to alternative and sustainable post-covid travel.

This work, without any pretense of being exhaustive, consists, in addition to the introduction, of four other paragraphs: 2. Rural tourism in the COVID-19 era, 3. Materials and Methods, 4. Sardinia's "staycation" itineraries, 5. Conclusions. The text aims, after a targeted review of the literature on rural tourism in this new pandemic era, to highlight how the rural areas of Sardinia can organize a structured offer of resources and services for a "cohesive" use of the territory. The organization of the offer will be exemplified, in the GIS field, by creating an accessibility model to the Sardinian rural space based on isochronous curves obtained from the analysis of travel times from the main active tourism reservoirs of the island to the farmhouses that offer accommodation and by the latter as part of their landscape offer.

\section{Rural tourism in the COVID-19 era}

The concept of rural tourism can be expressed in different forms based on the territory and the communities that are interested in it (Ana, 2017). In the European context, the definition adopted by the European Commission in 1998 is taken into consideration in which rural tourism is represented as "The activities of a person traveling and staying in rural areas (without mass tourism) other than those of their usual environment for less than one consecutive year for leisure, business, and other purposes (excluding the exercise of an activity remunerated from within the placed visited)" (Eurostat, 1998). The countryside close to urban centers was the first area to be affected by this practice and first of all involved the residents of the cities themselves who moved in search of recreational weekends away from the hectic urban pace (Battino, 2014). Starting from the seventies and eighties it has developed in different parts of the world and in its current configuration we can consider it as a real development strategy of inland areas, often marked by the phenomenon of depopulation and by the weakness of the socio-economic fabric (Brundu, 2018; Battino, Lampreu, 2019; Silva, 2021). The fragility of these districts is often contrasted with the richness of the natural and cultural heritage with enormous unfulfilled potential ${ }^{1}$. This tourist practice embraces various objectives ranging from landscape conservation to the growth of the economic value of the area, giving rise to a structured offer of goods and services that can increase the multifunctionality of places. In this new "guise" the rural area is reinterpreted and acquires the characteristics of a place of consumption and enjoyment, becoming the scene of various cultural, environmental, sports and educational and above all "tourist" initiatives. The attention of decision makers and policy makers has focused on the planning of an integrated offer of experiential tourist activities in which the physical paths (itineraries) emerge as glues of the individual company specificities. The multifunctional expression of the rural tourism sector is represented by hospitality organized mostly in the family environment such as the farm. In Italy, agritourism is governed by the National Law of February 20th, 2006, no. 96 in which the agro-pastoral activity of the entrepreneur is expected to remain the main source of income, while the catering, accommodation and entertainment of tourists are secondary and complementary. Staying on a farm allows tourists to have direct contact with the slow pace of agro-pastoral activities, resident communities, and cultural events

Development Programs (RDPs) at national and regional level to promote inclusive, cohesive, and sustainable development (https://ec.europa.eu/info/food-farming-fisheries/keypolicies/common-agricultural-policy/ruraldevelopment_it\#ruraldevelopmentprogrammes).

\footnotetext{
${ }^{1}$ For some time, Europe has taken steps to counter depopulation and the elements that increase the marginality of these areas. In this period of recovery from the restrictions of the COVID19 pandemic, the EU supports the rural world through the European Agricultural Fund for Rural Development 20212027 (EAFRD): funding that can be spent by the various Rural
} 
(Madau, 2007; Battino, 2014; Cevallos Suarez et al. 2020; Olimovich, 2020).

In the Italian context, this accommodation has always been one of the favorite destinations of visitors looking for relaxation away from the urban frenzy.

Before the health emergency, in 2019, the Italian market, of this form of rural tourism, recorded data on the rise compared to the previous year (2018): 24,576 authorized companies $(+4.1 \%)^{2}$ and $285,027(+8.5 \%)$ beds that hosted 1.9 million Italians and 1.8 million foreigners for a total of 14 million presences. The statistics highlight a lively sector of agriculture connected with tourism because the activities, services and goods offered (trekking, excursions, mountain biking, horseback riding, tastings, cooking classes etc. are multiple and diversified, depending on the territorial contexts). A dynamic sector that in 2020, due to the restrictions resulting from the pandemic, has registered declines. The ISMEA survey conducted on a sample of 500 agritourism businesses showed that $86 \%$ of them suffered significant losses deriving mainly from lost revenues from tourist services and $30 \%$, on the other hand, was affected by an increase in requests. by local tourists ${ }^{3}$ (ISMEA, 2020).

In the summer months, tourists, in search of a "new" normality, have chosen the proximity holiday in the open air and in safety in the mountains, by the sea or in the countryside. Among the Italian regions where this type of tourism emerges, Emilia-Romagna, Tuscany, TrentinoAlto Adige, Puglia, Campania and Sardinia are highlighted (Thomé Ortiz, 2020; ISTAT, 2021). To answer this question of proximity, the Regions have implemented a "survival" strategy to heal the losses. Rethinking the spaces that can be used in the open air involves the creation of a "network" of public and private actors to make the "deposits" of heritage "profitable" from an environmental, cultural, and economic point of view (Scopetta, 2012; Zukhri, Rosalina, 2020).

\section{Materials and methods}

The study area selected for the research was Sardinia a tourist region of Italy (Fig. 1). Traditionally this Island is famous for the marine tourism and only recently thanks to the policies of the Region and the combination of tourism and Information Communication Technology (ICT) it seems that a new image can be drawn. A more careful planning of the offer shows various and other territorial resources that are integrated or replaced with the activities of seaside tourism. Nature, culture, and local identity represent the key resources: "new" elements of attraction capable of enhancing localism, encouraging seasonal adjustment, and practicing more accurate environmental protection (Battino, 2014; Battino et al., 2018).

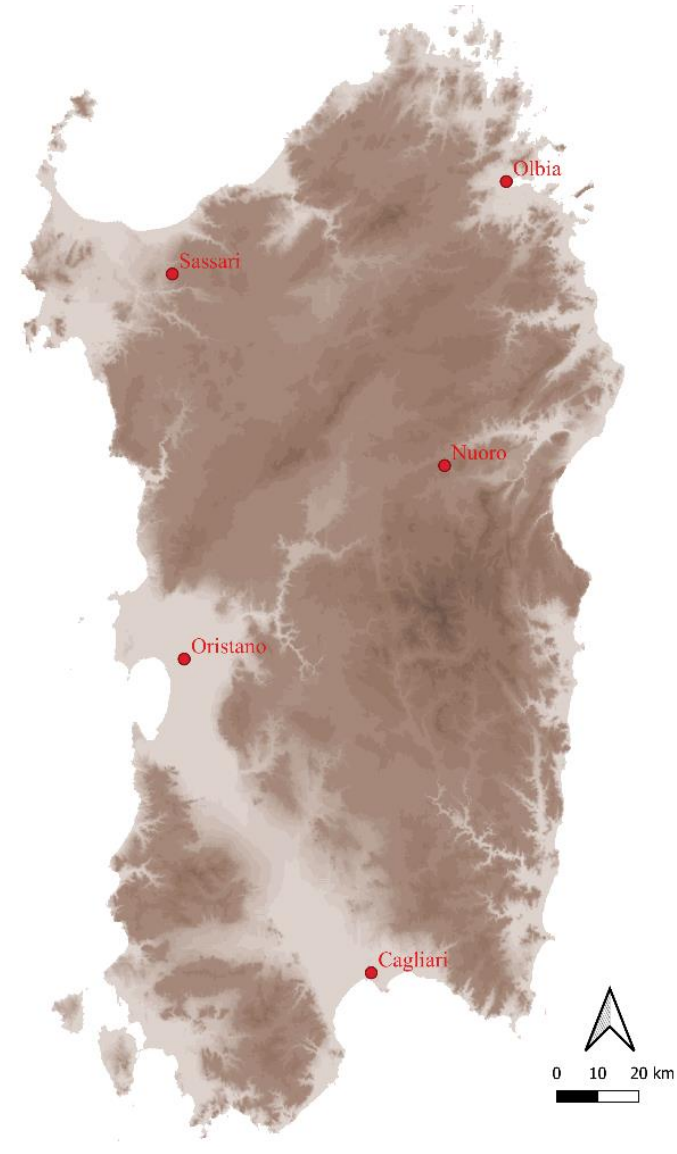

Figure 1. Location of the study area.

In this context, the objective of this work is to understand how to address the "new" demands of demand, bringing out the rich landscape heritage widely spread in the rural areas of the island through the creation of routes that revolve around the main accommodation facilities such as farmhouses. The exemplification of the creation of these itineraries is carried out in a GIS environment, using the QGIS software and the openrouteservice.org portal, through the creation of an accessibility model to the Sardinian rural space on which to order the isochronous

Statistics (ISTAT) which also notes how the personal means of transport (car) is the most used (74\%) precisely to avoid social contact as much as possible (ISTAT, 2021).

\footnotetext{
They are present in over 5,000 Italian municipalities and in areas with low population density (ISMEA, 2020).

3 The latter phenomenon is also confirmed by the "Travel and Holidays 2020" Report produced by the National Institute of
} 
curves obtained from the analysis of the distance to move towards the farms that offer accommodation, and also from these to reach the spaces of their landscape offer. To this end, to better identify the rural (internal) area as an example, some documents and databases have been studied and analyzed that clearly highlight the Sardinian situation. Among these we want to recall the regional documents relating to the strategy for the identification of inland areas and the study on the depopulation of the island's municipalities (Regione Sardegna, 2012, 2013 and 2014; Battino et al., 2018). With reference to the cartographic sources, the georeferenced information comes from the portal of the open data of the Sardinia Region (http://opendata.regione.sardegna.it) from which the basic datasets on the municipal and provincial administrative boundaries and on the census of landscape assets were obtained. The alphanumeric information relating to the system of agritourism activities active in 2021 comes, on the other hand, from the regional register of the multifunctionality of agricultural and fishing companies created by the regional agency for development in agriculture - Laore Sardegna (https: //www.agenzialaore. it / servizionline / SUAP.nsf / xpSezAgriturismo.xsp). This last dataset was georeferenced for its subsequent cartographic processing.

\section{Sardinia's "staycation" itineraries}

In recent years Sardinia has witnessed a wide spread of farmhouses from 506 in 2012 to $790^{4}$ in 2021 (data updated in June 2021 (https://www.agenzialaore.it/servizionline/SUAP.nsf/xpS ezAgriturismo.xsp).

Observing the distribution (Fig. 2), which highlights those exclusively dedicated to catering and the structures that also include the offer of beds, compared to the potential tourist "reservoirs" in the most important urban systems of the island (Cagliari, Olbia, Nuoro, Oristano) and to the 3 main Sardinian gateways ${ }^{5}$ (Alghero, near Sassari, Olbia and Cagliari), it is clear that the density of these structures is greater in their proximity since by calculating the travel times on the main roads they are arranged above all in the

${ }^{4}$ In provincial ranking of the presence of agritourism structures in the area, the Province of Sassari emerges with 312 structures of which 250 are organized for hospitality, followed by the Province of Nuoro (182 of which 135 with accommodation), of Southern Sardinia (160 of which 128 with accommodation), Oristano (103 of which 89 with accommodation) and Cagliari - Metropolitan City (33 of which 21 with accommodation).

5 The cities of Alghero, Cagliari and Olbia represent the three main airport connection poles of the island. According to the first ranges, between 0 - 30 minutes. This confirms that it is precisely these areas, through the demand addressed to them for rural tourism, that favor the birth of agritourisms in their vicinity.

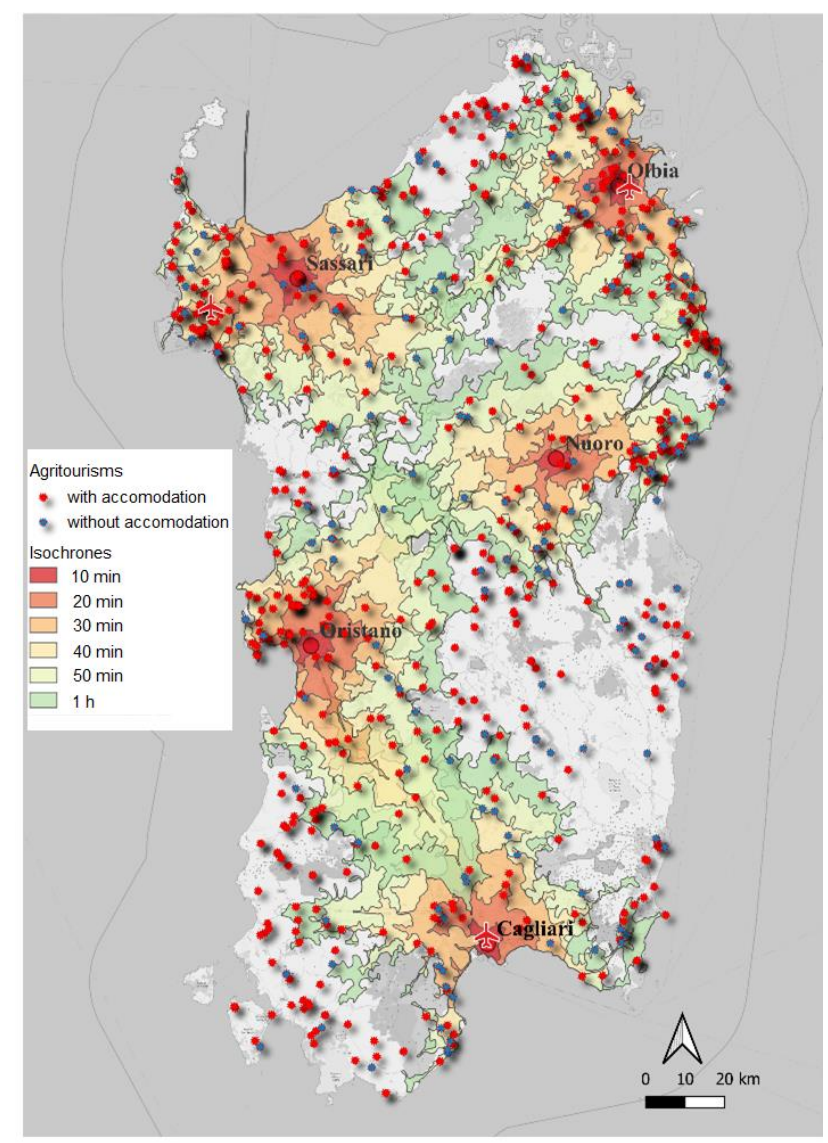

Figure 2. Map of the isochrones from the major cities of Sardinia and of Sardinian agritourisms differentiated between those with accommodation and those that provide only food and/or other services.

In the areas further away from these basins, the number of farmhouses is much lower and seems to coincide with the definition of "Internal Areas" found in the art. 174 of the Treaty on the Functioning of the European Union which understands them as the majority part of the Italian territory characterized by the significant distance from the centers of supply of essential services. A mapping has been proposed for these areas, which classifies them in

global data of 2019 relating to arrivals / departures Cagliari ranks first with 4,747,806 passengers followed by Olbia $(2,978,769)$ and Alghero $(1,390,379)$. While as regards the port classification, still in 2019, we find Olbia with 3,121,294 total passengers followed by Porto Torres $(1,116,242)$, Portoscuso-Portovesme (844,763), Golfo Aranci $(618,003)$, Cagliari-Sarroch $(593,271)$ and Oristano (288.849) (https://assaeroporti.com/; https://www.assoporti.it/it/home/). 
intermediate areas, peripheral areas, and ultra-peripheral areas. The subdivision considers a series of indicators not only related to the distance from the centers but also to one's state of malaise (https://www.agenziacoesione.gov.it/strategia-nazionalearee-interne/la-selezione-delle-aree/).

The distance from the main airports also seems to influence the distribution of the agritourism, as well as in the suburbs of the municipalities, since most of these structures are located more near the main Sardinian port and airport gateways. The latter are also located in coastal areas and cities where, taking advantage of seaside tourism, we find most of the farmhouses at a travel distance of about an hour.

Going further, sometimes the conditions of the Sardinian roads make the distances of the inland areas even greater than those in kilometers, so it takes a much longer time than an hour to travel $100 \mathrm{~km}$. Even some areas located near the coast, despite having a minimum tourist flow, suffer from the distance from the airports, well over an hour's journey, which influences in determining a low number of farmhouses.

The distance of the main gateways from some provincial centers (Fig. 3), especially Nuoro and Oristano, further affects the areas located on isochrones greater than one hour compared to these cities. There is therefore an almost direct relationship between periphery and isochronous which, although it cannot be explored in this work, it would be useful and interesting to further examine. Improving the travel times of the roads to the areas where the malaise is highest could have a positive effect, especially in increasing tourist flows to these areas.

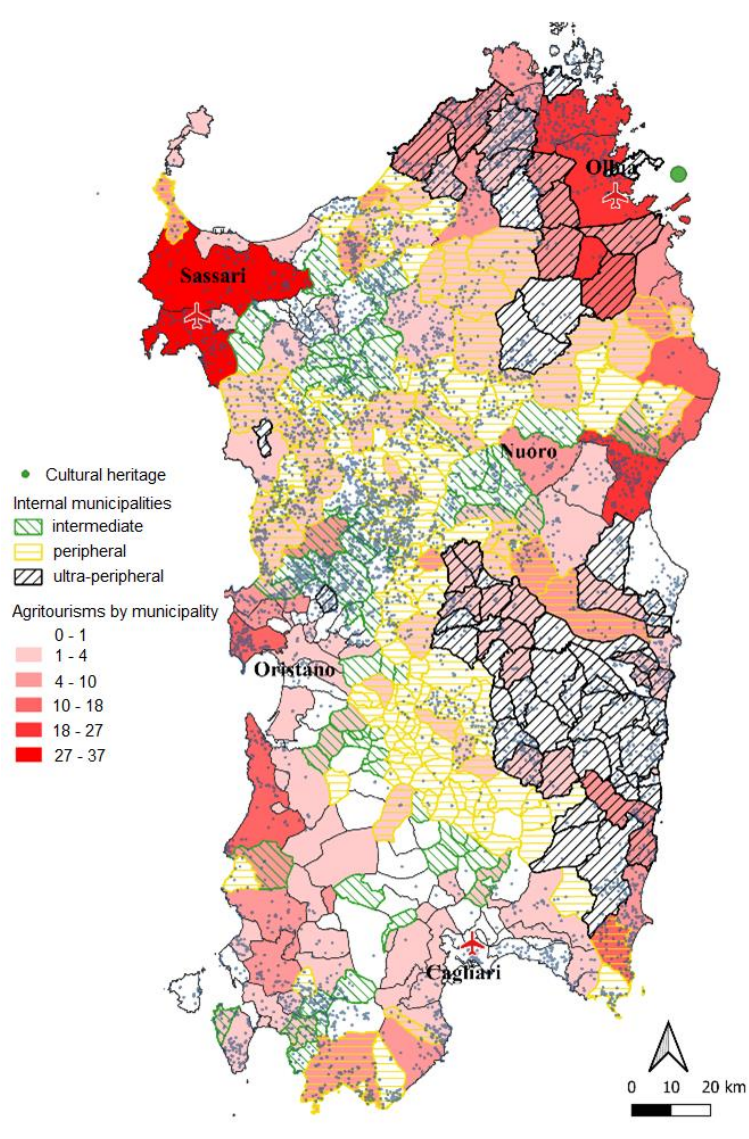

Figure 3. Map of municipalities based on the number of agritourisms, their degree of peripheral level and cultural heritage.

As already stated, in the areas of Sardinia close to the airports and where important environmental and cultural assets are found, the density of agritourisms that can also provide accommodation is very high (Fig. 3), on the other hand, far from them there is a low presence of agritourisms with overnight services, although there are often also in these places many resources of such importance.

For these structures, as in the example shown here (Fig. 4), it is easy to build interesting itineraries based on the isochrones to make the tourist experience more appreciable.

The example considered is that of a farmhouse located in the municipality of Alghero, in the locality of Santa Maria La Palma, - a few minutes from the airport and the port of Porto Torres, - which receives most of its guests in the summer, while in the other seasons it is frequented above all by the inhabitants of the metropolitan city formed around Sassari. Here it is possible to see the double value of a structure that exploits summer tourism, represented above all by non-Sardinians, and the off-season tourism of the inhabitants of the nearest towns. These tourist flows are 
however divided between the large number of farmhouses that persist in the area.

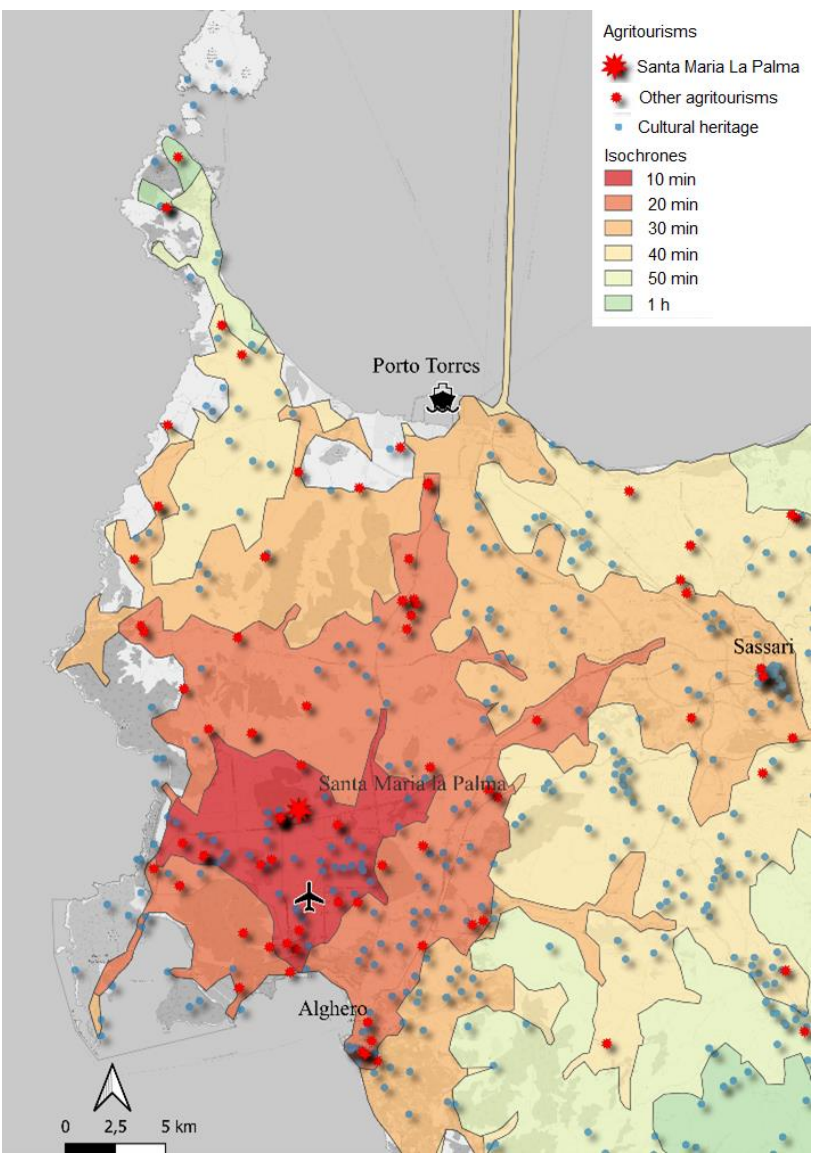

Figure 4. Example of isochronous compared to an agritourism in the Municipality of Alghero (Santa Maria la Palma).

The situation is much more complicated for agritourisms present in internal areas where only a few are currently able to provide accommodation and services of a higher level, now considered a standard in those in the areas previously indicated. For these structures (Fig. 5) it would be necessary to create routes that revolve around the farmhouses, linking the tourist experience of these structures to the beauty of the territories that in the internal areas, often more than in the coastal ones, are rich in cultural and environmental, some of which are rare and of indisputable value.

To better show the important value of the creation of these itineraries, an agritourism facility located in one of the many peripheral areas of the island, in the municipality of Tonara in the Province of Nuoro, was considered as a further example, and isochrones have been outlined with respect to the placed near it. The result, even if derived from a random choice, shows what is the ordinary situation in these areas where, if you manage to overcome the initial difficulty that you might have in reaching the structure in a short time it is possible to reach a large number of goods important environmental and cultural events. In the case considered, there are both cultural assets and sites of community importance within the isochrone.

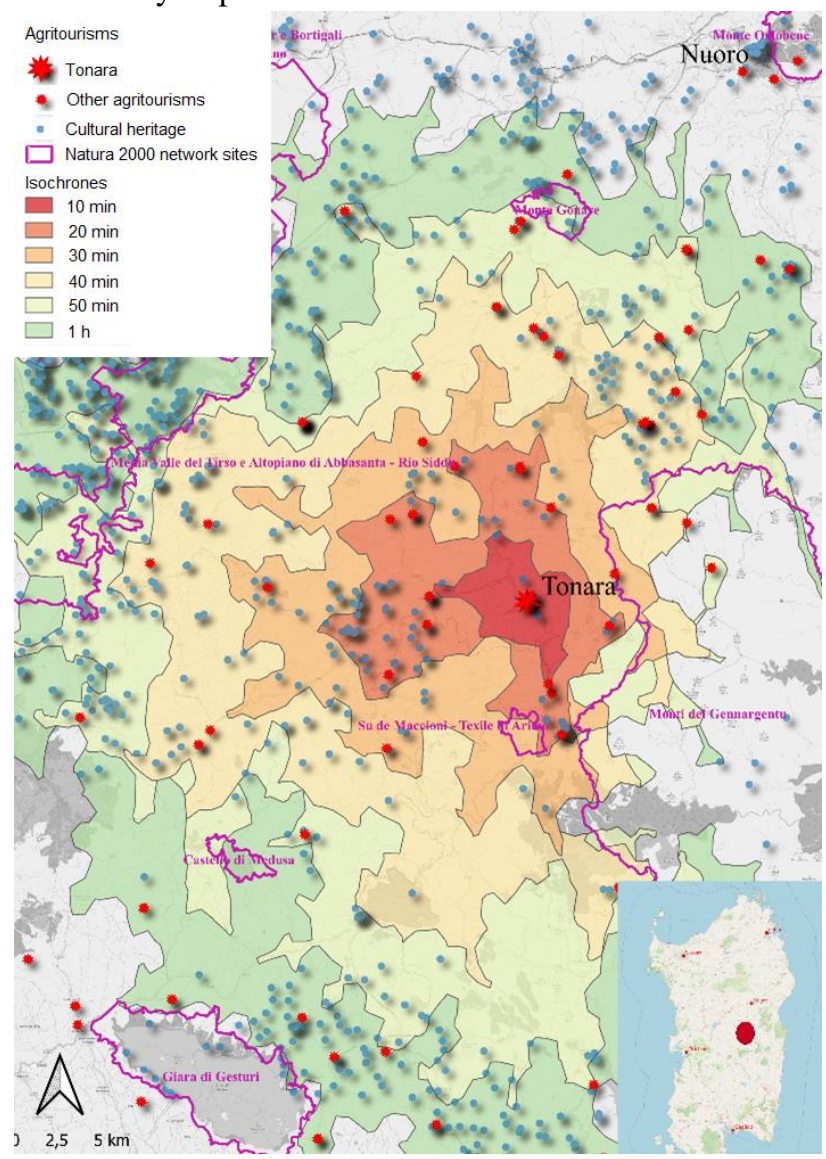

Figure 5. Example of isochronous compared to an agritourism in an internal area with demographic malaise (Municipality of Tonara).

The construction of possible itineraries using the isochrones less time away from the farm combined with a good marketing plan and an improvement in the usability of the assets through the creation of suitable structures around them and the presence of competent guides, could be useful to increase tourist flows in these areas which today suffer from the absence of useful interventions to exploit those economic resources that tourism is able to bring with it. The tourist flows exploited today are those coming from the neighboring cities mainly Nuoro and to a small extent Oristano.

\section{Conclusions}

The phenomenon of staycation appears for Italy as a new form of tourism dictated by the complex problems created in this segment of the economy, but also with profound social implications, created in the periods of "deceleration" of the pandemic state produced by COVID-19. Proximity 
tourism, defined as "a model of short-range tourism, concentrated on the national territory and mainly on destinations not very far from the area of residence (Morvillo, Becheri, 2020, p. 69), has entered the summer period 2020 and the trend has also been confirmed for the current 2021.

To confirm this trend there is also a study carried out by TripAdvisor, which since March 2021 predicted that 21\% of Italian travelers would spend their summer holidays very close to their area of residence while $16 \%$ would go to destinations around 90 minutes from your city or a little further on. The study states that this trend, in 2020, has partly saved the economy of many tourist destinations that are usually crowded with foreign tourists (https://siviaggia.it/notizie/video/turismo-prximita-2021confermata-tendenza-scorso-anno/324398/).

A further and more recent survey conducted by "CNA Turismo e Commercio" in the first days of August 2021 states that it will be a record August for domestic tourism and predicts better numbers than even those recorded in 2019, as 13 million Italian tourists are expected (three million more than in 2019). A consistent presence will also be represented by the foreign component, albeit much less than in previous years. Preferred places will be the classic seaside resorts, followed at a distance by mountains, spas, etc.

The favored accommodation facilities are the classic hotels, possibly with their own reserved areas such as private beaches, spas, thermal services. Even if the extrahotel structures, represented by bed \& breakfasts, residences, agritourisms, camping, etc. appear more and more sought after (https://www.cna.it/turismo-indaginecna-ferragosto-e-gia-tutto-esaurito/).

The national context is well reflected in the current tourist season in Sardinia, which has always been a privileged destination for both the Italian and foreign components. In this short study, a further and still little practiced way of doing tourism on the island is highlighted, however, the construction of possible itineraries using the isochrones at a shorter distance from the farmhouses in the internal areas, combined with a good marketing plan and a improvement in the usability of the assets through the creation of adequate structures and infrastructures ${ }^{6}$ around them, could be useful in increasing the tourist flows in these areas which today suffer from the absence of

6 The history of road infrastructures in Sardinia is very complicated because the morphology and the scarcity of arteries that connect it to the biggest urban centers has delayed its development. In fact, if we calculate kilometric and linear distances between the Municipality of Tonara, chosen as an example of inland area (Fig. 5), we can see that between it and interventions capable of exploiting the related activities that always accompany the tourist activity. The internal area set as an example benefits from tourist flows of greater proximity, such as those coming from the nearest cities, mainly Nuoro and Oristano, the distance from the main island gateways, but also the long travel times of these relative short sections from the larger ones. city of the island, makes them less attractive for tourism which at certain times of the year can be replaced by hiking.

However, as Mangano (2020) affirms, in this case, the difficulties can represent an opportunity: redesigning the Island's geography of tourism seems important in order to offer "new" itineraries of the internal areas that are easy to access in order to be enjoyed by locals and tourists in a concept of multi-scalar staycation.

\section{References}

Ana, I. M. (2017). Ecotourism, agro-tourism and rural tourism in the European Union. Cactus Tourism Journal $15 / 2), 6-14$.

Battino, S. (2014). Turismo sostenibile in Gallura: prospettiva vincente o modello illusorio? I principali caratteri distintivi del cuore turistico della Sardegna, Patron editore, Bologna.

Battino, S., Balletto, G., Borruso, G. and Donato, C. (2018). Internal Areas and Smart Tourism. Promoting Territories in Sardinia Island. In Gervasi O. et al. (eds.), Computational Science and Its Applications - ICCSA 2018. ICCSA 2018. Lecture Notes in Computer Science, 10964, Springer, Cham, 44-57.

Battino, S. and Lampreu S. (2019). The Role of the Sharing Economy for a Sustainable and Innovative Development of Rural Areas: A Case Study in Sardinia (Italy), Sustainability, 11 (3004), 1-20.

Brundu, B. (2018). Rural development policies as a precondition for a revival of marginal areas. In Cejudo Garcìa, E., Navarro Valverde, F.A. and Camacho Ballestra J.A. (eds.). Nuevas realidades rurales en tiempos de crisis: territorios, actores, procesos $\mathrm{y}$ políticas. Actas de XIX Coloquio de Geografía Rural, Editorial Univerdidad de Granada, 565-577.

Cevallos Suarez, M. P., Cevallos Pinguil, T. C. and Cabanilla Vásconez, E. A. (2020). Enfoques del

the city of Cagliari (port, airport), the nearest gateway to the locality, as the crow flies there are only $88 \mathrm{~km}$ of distance while at the level of the road there are $125 \mathrm{~km}$ that can be covered in 1 hour and 55 minutes (https://distanzechilometriche.net/). 
desarrollo en espacios rurales:a propuesta agro-turística comunitaria. In Zizumbo Villarreal, L., Monterroso Salvatierra, N. (eds.). Comunidades, territorios y turismo en América Latina. Editorial Torres Asociados: Mexico.

Eurostat (1998). Community Methodology on Tourism Statistics. European Commission. Luxembourg.

Everingham, P. and Chassagne, N. (2020). Post COVID19 ecological and social reset: moving away from capitalist growth models towards tourism as Buen Vivir. Tourism Geographies 22 (3), 555-566.

Fletcher, R., Murray, Mas I., Blazquez-Salom, M. and Blanco-Romero, A. (2020). Tourism, degrowth, and the COVID-19 Crisis. Political Ecology Network. Available online:https://politicalecologynetwork.org/2020/03/24/t ourism-degrowth-and-the-covid-19-crisis/.

Gossling, S., Scott, D. and Hall, M. (2020). Pandemics, tourism and global change: a rapid assessment of COVID-19. Journal of Sustainable Tourism 29 (1): 1-20.

Ioannides, D. and Gyimóthy, S. (2020). The COVID-19 crisis as an opportunity for escaping the unsustainable global tourism path. Tourism Geographies 22 (3), 624632.

ISMEA (2020). Agriturismo e multifunzionalità. Scenario e prospettive. Rapporto 2020. Available online: http://www.ismea.it/flex/cm/pages/ServeBLOB.php/L/I T/IDPagina/11292.

ISTAT (2021). Viaggi e vacanze in Italia e all'estero. Anno 2020. Available online: https://www.istat.it/it/files//2021/04/Report_viaggiVaca nze_2020.pdf.

Madau, C. (2007). Percorsi di sostenibilità: l'esperienza dell'agriturismo in Sardegna. In Donato, C. (ed.). Turismo rurale, agriturismo ed ecoturismo quali esperienze di un percorso sostenibile, EUT Edizioni Università di Trieste, Trieste, 85-107.

Mangano, S. (2020). Il turismo di prossimità per (ri)scoprire il territorio italiano in tempi di crisi, Aracne editrice, Roma.

Morvillo, A. and Becheri, E. (2020). Dalla crisi alle opportunità per il futuro del turismo in Italia, Rogiosi editore, Napoli.

Olimovich, S. (2020). Agrotourism as one of the prospective directions of the tourist industry. The America Journal of Social Science and Education Innovations, 2 (09-39), 254-259.

Regione Sardegna (2012). Indice di Deprivazione Multipla della Sardegna, Assessorato della Programmazione, Bilancio, Credito e Assetto del Territorio, Cagliari.
Regione Sardegna (2013). Comuni in estinzione. Gli scenari dello spopolamento in Sardegna, Centro Regionale di Programmazione, Cagliari.

Regione Sardegna (2014). La Strategia Nazionale per le aree interne. Processo programmatico e nota metodologica per l'individuazione delle aree interne per la Regione Sardegna, Cagliari.

Scoppetta, C. (2012). Nuove geografie dell'autoorganizzazione. Planum. The Journal of Urbanism, 2 (25), 1-7.

Sharma, D. G., Thomas, A. and Paul, J. (2021). Reviving tourism industry post-COVID.19: a resilience-based framework. Tourism Management Perspectives 37, 100786, 1-10.

Silva, L. (2021). The impact of the COVID-19 pandemic on rural tourism: a case study from Portugal, Anatolia, 14.

Thomé Ortiz H. (2020). O coronavírus reescreverá o turismo rural? Reinvenção, adaptação e ação no contexto latino-americano. Cenàrio - Revista Interdisciplinar em Turismo y Territòrio, 8 (14), 55-72.

Zukhri, N. and Rosalina, E. (2020). Acceleration model for tourism industry recovery based on environment post COVID-19. IOP Conf. Ser.: Earth Environment Science, 599, 012090, 1-7.

This paper is the result of the joint work of the authors. In particular: paragraphs 1 and 5 have been written by $\mathrm{B}$. Brundu; paragraphs 2 and 4 have been written by $S$. Battino; paragraph 3 has been written by I. Manca. The images were processed by I. Manca. 